\title{
STUDI LITERATUR KEPEMIMPINAN WIRAUSAHA DALAM MENGHADAPI TANTANGAN GLOBAL
}

\author{
Safuan \\ E-mail: safuan777@gmail.com \\ Jurusan Teknik Industri, Fakultas Teknik Universitas Muhammadiyah Jakarta \\ Jl. Cempaka Putih Tengah 27 Jakarta Pusat 10510
}

\begin{abstract}
The progressions have raises new standards and every organization is required to roll out improvements quick, right and adaptable, in light of the fact that generally the organization will be hard to contend all around later on. The ramifications of worldwide ecological change expects organization to change the methodology of the organization that initially situated to nearby all inclusive arranged, to the organization without bounds should dependably be inviting to future hierarchical changes keeping in mind the end goal to have the capacity to be leaders of progress later on. It takes entrepreneurial leadership to react to difficulties of worldwide change with the goal that the organization can adjust and still exist in zone of worldwide rivalry.
\end{abstract}

Keywords: Leadership, Global, Entrepreneurship

\begin{abstract}
Abstrak
Perubahan telah memunculkan aturan baru dan setiap organisasi dituntut untuk melakukan perubahan dengan cepat, tepat serta fleksibel, karena jika tidak demikian maka organisasi akan sulit untuk bersaingan secara global di masa yang akan datang. Implikasi dari perubahan lingkungan global menuntut organisasi untuk merubah strategi organisasi yang semula local oriented menjadi global oriented, untuk itu organisasi kedepannya harus selalu bersahabat dengan perubahan agar kedepan organisasi dapat menjadi pemimpin perubahan dimasa yang akan datang. Dibutuhkan pemimpin yang berjiwa entrepreneur untuk menghadapi tantangan perubahan global tersebut sehingga organisasi dapat beradaptasi serta tetap eksis dikancah persaingan global.
\end{abstract}

Kata Kunci : Kepemimpinan, Global, Wirausaha

\section{PENDAHULUAN}

Tahun 2018 merupakan tantangan berat yang harus dihadapi Indonesia dalam menghadapi era persaingan global. Era persaingan global yang tanpa batas yang ditandai dengan cepatnya perubahan dalam lingkungan bisnis, kemajuan teknologi komunikasi dan informasi, serta teknologi lainnya menjadi kenyataan yang harus disikapi dengan bijak dan cermat agar organisasi dapat tetap eksis dalam kancah persaingan global.
Dalam kondisi di atas, maka diperlukan kehadiran seorang leader yang memiliki visi jauh ke depan, kepemimpinan yang memiliki sense of change yang tinggi, pemimpin yang sadar akan posisinya di tengah-tengah lingkungan yang terus berubah, pemimpin yang memiliki jiwa dan semangat entrepreneurship. Pemimpin yang dapat berkomunikasi, mempunyai semangat dan berani mengambil risiko (McKinney Rogers Consultant, 2007).[1] 
Pemimpin yang tidak hanya menjadi agen perubahan tetapi sekaligus memimpin perubahan itu sendiri. Kepemimpinan strategis yang memiliki sense of business dan sense of change yang tinggi, mampu bertindak proaktif, kreatif dan inovatif. Sebagai seorang agen perubahan pada dasarnya harus memiliki tiga karakter utama, yaitu: (1) kreatif dan inovatif; (2) mampu bersikap sebagai intrapreneurship dan entrepreneurship bagi organisasinya, dan (3) memiliki kapasitas dan networking yang memadai. Ketiga karakter ini secara bersama-sama akan menjadi dasar seorang pemimpin mengambil sikap untuk proactive to change (Edi Prasetyo Nugroho dan Rina Elisaprapti, 2002). Kepemimpinan yang mampu menciptakan kondisi yang dapat menumbuhkan motivasi seluruh elemen organisasi untuk terus belajar dan berkembang.(Purhantara, 2010).[2]

Tantangan global mulai terasa berat di saat ekspor Indonesia pada bulan Juli 2014 mengalami penurunan sebesar hingga 6,03 persen di bandingkan Juli 2013, atau sebesar US\$ 15,41 miliar (Suryamin, 2014).[3] Belum lagi akan diberlakukannya era pasar bebas yaitu Masyarakat Ekonomi Asean (MEA) dan AFTA yang menjadi tantangan sekaligus peluang yang ada didepan mata.

Dalam menghadapi realita ini, dibutuhkan pemimpin yang dapat menjawab tantangan dan peluang tersebut. Bukan pemimpin yang merasa nyaman dengan keadaan sekarang atau comfort zone dan tidak mau berpindah dari keadaan ini. Bukan pemimpin yang hanya wait and see atau melakukan transformasi konvensional namun pemimpin yang bisa melihat celah dan kesempatan serta dapat mengadaptasi perubahan secara radikal, membongkar comfort zone di dalam maupun di luar. Pemimpin seperti ini biasa disebut crackers (Suyatno, 2014).[4]

Pemimpin tersebut juga harus merubah paradigma berfikir menghadapi perubahan lingkungan bisnis yang sangat cepat, dari budaya birokrasi menjadi corporate culture, membenahi tata kelola organisasi yang transparan dan bebas korupsi. Serta mendayagunakan dan menyelaraskan seluruh organ dari seluruh organisasi dengan strategi utama sehingga organisasi memiliki daya saing serta menerapkan budaya pembelajaran.

Untuk itu, perlu dikembangkan sistem pembentukan karakter bagi sumber daya manusia di Indonesia yang memiliki sifat entrepreneurial leadership sehingga mampu menjawab tantangan seperti terungkap pada paragraf sebelumnya. Pertanyaan selanjutnya adalah apakah kemampuan entrepreneurship pada seseorang dapat dikembangkan atau bawaan dari lahir? Menurut hasil survey yang dilakukan oleh McKinney Rogers Consultant bahwa 51 persen persepsi pengusaha adalah kewirausahaan dapat dikembangkan dan mayoritas responden sebesar 69 persen melihat pentingnya kewirausahaan dalam organisasi (McKinney Rogers Consultant, 2007).

\section{Tinjauan Pustaka}

\subsection{Pengertian Kepemimpinan}

Menurut Rost (Rost, 1993)[5], kepemimpinan adalah hubungan pengaruh antara pemimpin dan pengikut yang berniat perubahan yang nyata yang mencerminkan tujuan bersama mereka. Sedangkan menurut Robbins dan Judge (Robbins dan Judge, 2013)[6], kepemimpinan adalah kemampuan untuk mempengaruhi suatu kelompok ke arah pencapaian visi atau serangkaian tujuan. Masih menurut Robbins dan Judge Organisasi membutuhkan kepemimpinan yang kuat dan manajemen yang kuat untuk efektivitas optimal. Saat ini organisasi perlu pemimpin untuk menantang status quo, menciptakan visi masa depan, dan mengilhami anggota organisasi agar mau mencapai visi. Organisasi juga membutuhkan manajer untuk merumuskan rencana rinci, 
menciptakan struktur organisasi yang efisien, dan mengawasi operasi sehari-hari.

Menurut Armstrong (Armstrong, 2009)[7], kepemimpinan adalah Kapasitas untuk menginspirasi individu untuk memberikan kemampuan terbaik mereka untuk mencapai hasil yang diinginkan dan untuk menjaga hubungan yang efektif dengan individu dan tim secara keseluruhan. Menurut Wilkins dan Carolin (Wilkins dan Carolin, 2013)[8] mengutip pernyataan Eisenhower kepemimpinan adalah seni mendapatkan orang lain untuk melakukan sesuatu yang ingin Anda lakukan karena dia ingin melakukannya.

Kepemimpinan menurut Bass [9] adalah interaksi antara dua atau lebih anggota kelompok yang sering terlibat untuk penyusunan penataan kembali situasi dari persepsi dan harapan para anggota. kepemimpinan telah dipahami sebagai fokus proses kelompok, sebagai atribut kepribadian, sebagai seni merangsang kepatuhan, sebagai latihan pengaruh, sebagai jenis tertentu kegiatan, sebagai bentuk persuasi, sebagai relasi kekuasaan, sebagai instrumen dalam pencapaian tujuan, sebagai akibat dari interaksi, sebagai peran yang berbeda, dan sebagai inisiasi struktur. Sedangkan menurut Drucker seperti yang dikutip oleh Hesselbein dan Goldsmith (Hesselbein dan Goldsmith, 2006)[10], kepemimpinan berkaitan dengan menciptakan organisasi yang memiliki semangat kinerja yang tinggi. Untuk mencapai semangat kinerja, pemimpin harus;

a. dengan bukti integritas tinggi dalam perilaku moral dan etika mereka.

b. fokus pada hasil.

c. membangun sendiri kekuatan-satu dan lainnya.

d. memimpin dengan di luar batasan untuk memenuhi setidaknya persyaratan minimum dari semua pemangku kepentingan, termasuk pelanggan, pemegang saham, dan masyarakat, serta melayani kepentingan umum.

Menurut Lussier dan Achua (Lussier dan Achua, 2010)[11], Kepemimpinan adalah proses yang berpengaruh dari pemimpin dan pengikut untuk mencapai tujuan organisasi melalui perubahan.

\subsection{Pengertian Entrepreneurship (Wirausaha)}

Wirausaha menurut Choo dan Bontis (Choo dan Bontis, 2002) didefinisikan sebagai proses menemukan, mengenali, dan memanfaatkan peluang-peluang baru. Sedangkan menurut Baron dan Shane, wirausaha sebagai bidang bisnis, berusaha untuk memahami bagaimana peluang untuk menciptakan sesuatu yang baru (misalnya, produk atau jasa baru, pasar baru, proses produksi baru atau bahan baku, cara-cara baru pengorganisasian teknologi yang sudah ada) muncul dan ditemukan atau diciptakan oleh individu tertentu, yang kemudian menggunakan berbagai cara untuk mengeksploitasi atau mengembangkan mereka, sehingga menghasilkan berbagai dampak.

Wirausaha menurut Reynolds (Reynolds, 2007)[12] adalah tentang melakukan sesuatu yang berbeda menciptakan bisnis yang tidak ada, menghasilkan produk baru, memodifikasi kegiatan yang ada. Drucker (Drucker, 2002)[13] menggambarkan pengertian dari entrepreneurship dengan mencontohkan McDonald sebagai perusahaan yang menerapkan konsep manajemen dan teknik manajemen (bertanya, Apa arti nilai kepada pelanggan?), Standardisasi produk, merancang proses dan perangkat, dan dengan mendasarkan 
pelatihan tentang analisis pekerjaan yang harus dilakukan dan kemudian menetapkan standar yang diperlukan, McDonald secara drastis dapat meningkatkan hasil dari sumber daya, dan menciptakan pasar baru dan pelanggan baru. Ini adalah wirausaha.

Wirausaha menurut Hisrich, Peter dan Shepherd yang dikutip oleh Wijatno (Wijatno, 2011)[14] adalah proses menciptakan sesuatu yang baru, yang bernilai, dengan memanfaatkan usaha dan waktu yang diperlukan, dengan memperhatikan risiko sosial, fisik, dan keuangan, dan menerima imbalan dalam bentuk uang dan kepuasan personal dan indepedensi.

\subsection{Kepemimpinan (Entrepreneurial Leadership)}

Menurut Greenberg et al. (Greenberg et al, 2011)[15] kepemimpinan wirausaha melibatkan model baru pemikiran dan tindakan, yang dimulai dengan pandangan dunia yang berbeda secara fundamental dari bisnis dan menerapkan pengambilan keputusan yang tidak logis.

Sedangkan menurut Afiff (Afiff, 2012)[16], Perusahaan berbasis kewirausahaan memiliki kelebihan dimana kinerja kepemimpinan memiliki ruang gerak yang lebih leluasa. Berbeda dengan perspektif organisasi secara umum dimana aspek kepemimpinan lebih dibatasi oleh pengaturan organisasi, maka beberapa aspek perusahaan berbasis kewirausahaan lebih memungkinkan memfasilitasi kemampuan pemimpin untuk mempengaruhi perubahan dan kinerja. Ternyata ukuran perusahaan merupakan faktor penting dalam melaksanakan kebijakan manajerial.

\subsection{Pengembangan \\ Wirausaha \\ Leadership)}

Kepemimpinan

(Entrepreneurial

Pengembangan SDM berjiwa Kepemimpinan Wirausaha di Indonesia dapat ditempuh dengan 2 pendekatan yaitu pendekatan Makro dan Mikro. Pada tahap makro ini merupakan ranah pemerintah dalam mengembangkan SDM secara global melalui perencanaan program pendidikan dan pelatihan dalam skala nasional. Pada tahap mikro ini merupakan ranah organisasi seperti perusahaan dimana setiap perusahaan melakukan pendidikan dan pelatihan Leadership dan Entrepreneurship kepada karyawan sehingga perusahaan nantinya akan dapat mencetak karyawan dengan jiwa Kepemimpinan Wirausaha yang berguna bagi perusahaan kelak dikemudian hari, sekaligus menjawab tantangan bagi perusahaan untuk bersaing secara global.

Dalam pengembangan SDM berjiwa kepemimpinan wirausaha dapat di lihat dari 3 prinsip kepemimpinan wirausaha (Greenberg et al., 2011) yaitu :

\section{a. Cognitive Ambidexterity}

Kepemimpinan wirausaha melibatkan kedua logika prediksi dan logika kreasi dalam pendekatan pengambilan keputusan mereka.

\section{b. SEER (Social, Environmental, and Economic Responsibility and Sustainability)}

Tanggung jawab dan berkesinambungan, Kepemimpinan wirausaha harus tahu bagaimana untuk mengarahkan penciptaan nilai sosial, lingkungan, dan ekonomi dan 
ketegangan yang melekat dan potensi sinergi di dalamnya. Selain itu mereka harus belajar untuk terlibat penciptaan nilai sosial, lingkungan, dan ekonomi secara simultan daripada secara berurutan. Diluar SEER, kepemimpinan wirausaha juga memanfaatkan pemahaman mereka tentang diri mereka sendiri dalam konteks sosial untuk memandu tindakan yang efektif.

\section{c. SSA (Self and Social Awareness)}

Melalui pemahaman otentik dan mendalam dari kesadaran akan tujuan dan identitas mereka sendiri dan bagaimana mereka dipengaruhi oleh konteks sekitar mereka, para pemimpin wirausaha membuat keputusan yang lebih efektif dalam keadaan tidak pasti dan tidak dapat diketahui.

Setelah mengetahui 3 prinsip kepemimpinan wirausaha maka selanjutnya adalah bagaimana langkah pengembangan SDM ke arah 3 prinsip kepemimpinan wirausaha tersebut? Berikut ini langkah pengembangan SDM berjiwa kepemimpinan wirausaha mengacu kepada ke-3 prinsip di atas, antara lain:

\section{a. Sebuah Cara Baru dalam Berpikir dan Bertindak: Mengembangkan Cognitive Ambidexterity.}

Bagaimana mengembangkan pola pikir ini dalam kepemimpinan wirausaha? Prinsip di balik ambidexterity kognitif adalah bahwa para pemimpin wirausaha harus bergantung pada pendekatan analistis yang bervariasi dengan melengkapi pikiran dan tindakan menciptakan dan menerapkan solusi secara sosial, lingkungan, dan ekonomi berkelanjutan.
Selanjutnya yang harus dikembangkan adalah cara berfikir kepemimpinan wirausaha tentang bagaimana dan kapan dibutuhkan menggunakan pendekatan analistis. Logika prediksi, penggunaan pendekatan analitis tradisional, merupakan perpanjangan dari metode ilmiah untuk berpikir, mengevaluasi, dan kemudian bertindak untuk merubah sebuah organisasi ke arah tujuan yang telah ditetapkan.

Kemudian dasar pemikiran yang mendasari prediksi logika adalah bahwa seseorang dapat melindungi atau mengontrol masa depan melalui analisis rinci. Bagaimana cara mempraktekkan data mining, riset pasar, dan alat statistik tradisional untuk mengidentifikasi dan mengembangkan peluang. Pendekatan prediksi yang paling berlaku untuk situasi ini di mana tujuan yang telah ditentukan, masalah yang jelas, penyebab dan efek dipahami, dan data yang dapat diandalkan dan tersedia. Pendekatan prediksi mengasumsikan bahwa masa depan yang pasti dapat diprediksi dan bahwa keputusan dapat dibuat berdasarkan prediksi tersebut.

Namun pemimpin wirausaha juga menemukan bahwa diri mereka dalam situasi di mana hal-hal baru atau kompleksitas membatasi kemampuan prediktif mereka. Dalam keadaan fundamental baru atau kompleks di mana hubungan sebab-akibat tradisional tidak diketahui, tidak selalu bisa untuk mengumpulkan data yang sesuai atau menggunakan trend historis untuk terlibat prediksi pendekatan analitis. Dalam situasi yang tidak jelas ini, pemimpin wirausaha harus belajar untuk menerapkan logika yang berbeda yang didasarkan dengan tindakan, penemuan, dan penciptaan. Pendekatan ini disebut logika kreasi (creation logic).

Dari pengembangan pendekatan ini diharapkan semua pemimpin wirausaha perlu menggunakan kedua logika kreasi dan prediksi dan menjadi terampil dalam siklus antara keduanya karena mereka 
memperkenalkan ide-ide dan inisiatif baru. Secara bergantian menggunakan pendekatan antara kreasi dan prediksi memungkinkan individu dan organisasi untuk secara efektif berinovasi dalam mengelola perubahan.

\section{b. Sebuah Pandangan dunia Baru: Sosial, Lingkungan, dan Tanggung Jawab Ekonomi dan Kebersinambungan.}

Salah satu prinsip yang membuat pemimpin wirausaha yang unik adalah bahwa cara baru pengambilan keputusan didasarkan pada pandangan dunia yang berbeda secara fundamental. Selanjutnya adalah bagaimana mengembangkan pemimpin wirausaha yang memiliki pandangan dunia yang unik, dengan fokus khusus pada konsep tanggung jawab sosial, lingkungan, dan ekonomi secara keberlanjutan dan cara-cara inovatif untuk membantu para pemimpin wirausaha memahami pentingnya pandangan unik dari bisnis dan masyarakat .

Muncul realitas global, sosial, lingkungan, dan ekonomi mengharuskan kita untuk mengajarkan para pemimpin untuk mempertimbangkan isu-isu di luar maksimalisasi penciptaan laba dan nilai pemegang saham. Pemimpin wirausaha perlu mengembangkan pemahaman yang lebih kompleks hubungan antara penciptaan nilai sosial, lingkungan, dan ekonomi. Paradigma bisnis tradisional yang memfokuskan secara eksklusif pada penciptaan nilai ekonomi, atau yang menggambarkan penciptaan nilai sosial dan lingkungan sebagai bagian sekunder untuk penciptaan nilai ekonomi, hal ini tidak berlaku lagi. Individu dan organisasi semakin sering bertanggung jawab atas hasil-hasil sosial, lingkungan, dan ekonomi dari tindakan mereka.

Pemimpin wirausaha harus beroperasi dari pandangan dunia yang berbeda dari bisnis di mana mereka memahami ketegangan yang melekat dan potensi sinergi yang ada antara penciptaan nilai sosial, lingkungan, dan ekonomi. Untuk melakukan hal ini mereka juga harus belajar bagaimana menilai kepentingan, hak, dan kekuasaan dari kelompok yang sangat beragam dari pemangku kepentingan. Pemimpin wirausaha perlu belajar bagaimana mengembangkan, melaksanakan, dan mengukur dampak dari solusi yang bertanggung jawab dan berkelanjutan.

\section{c. Kesadaran Diri dan Sosial memberikan Panduan untuk Tindakan}

Bagaimana mengembangkan kesadaran diri pemimpin wirausaha dan kesadaran sosial serta mengajar mereka untuk memimpin dari semangat diri mereka. Prinsip ketiga kepemimpinan kewirausahaan ini melibatkan pengembangan pemahaman kritis dari diri mereka sendiri dan konteks sosial dari peluang bisnis. Pemahaman ini memberikan dasar untuk melakukan cara baru untuk mengetahui berdasarkan pandangan yang lebih luas dari bisnis. Dengan memulai dengan pemahaman kritis dari perspektif mereka sendiri dan dunia di sekitar mereka, para pemimpin wirausaha lebih siap untuk menerapkan perspektif beragam seperti mereka menanggapi situasi yang tidak pasti dan tidak diketahui. Mereka juga lebih siap untuk secara efektif menciptakan program tindakan yang sedang berlangsung dan untuk menegosiasikan hasil yang tidak pasti dan tidak jelas yang dapat timbul dari pengambilan keputusan mereka.

Akhirnya, pemimpin wirausaha yang telah mengembangkan pemahaman ini akan kaya perspektif dapat melibatkan pemahaman yang lebih canggih dari satu dunia yang memungkinkan mereka untuk melihat implikasi tindakan sosial, lingkungan, dan ekonomi. Untuk mengembangkan hal ini, pemimpin wirausaha harus mampu menggali pertanyaan-pertanyaan kritis: Siapa saya? Apa konteks di mana saya berada? apa yang saya ketahui, dan siapa yang dapat memberikan saya akses? Memahami pertanyaan-pertanyaan ini memungkinkan pemimpin wirausaha untuk membuat pilihan yang bertanggung jawab karena mereka 
memilih jalan tindakan dalam kedua situasi yang tidak bisa diketahui dan tidak pasti.

\subsection{Pemimpin yang Berkualitas "Entrepeneurship Leadership"}

Dari hasil pengembangan kepemimpinan wirausaha di atas dan menyikapi adanya tuntutan dan tantangan yang berkembang dalam era globalisasi ini, maka diharapkan tercipta generasi pemimpin yang berkualitas 'entrepreneurial leadership' antara lain (Purhantara. 2010):

1) Kepemimpinan (leadership) yang dinamis dan efektif. Kepemimpinan ini bisa diartikan sebagai suatu upaya menanamkan pengaruh bukan paksaan untuk memotivasi dan menggerakkan (pihak lain seperti) : karyawan, bawahan, dan masyarakat sehingga mereka bekerja sesuai dengan kehendak pimpinan yaitu pencapaian tujuan (strategis) organisasi. Dalam menjalankan fungsi pimpinan ini (untuk menggerakkan para anggota organisasi) diperlukan ketrampilan atau pengetahuan tentang komunikasi serta faktor-faktor yang mendorong seseorang untuk bekerja (motivasi).

2) Mempunyai profesionalisasi kepemimpinan yaitu mau dan mampu membawa teamwork untuk selalu kreatif, inovatif, dan mencari berbagai alternatif peluang dengan keberanian mengambil risiko.

3) Memiliki keahlian (expertise) dan kompetensi dalam satu atau beberapa bidang dan menjadi seorang pemikir yang intuitif (pencari peluang) bukan pemikir sistemik (pengatur kerja).

4) Mempunyai jiwa dan semangat kewirausahaan yang tinggi untuk mampu melihat, mengindentifikasi, mendayagunakan, dan menciptakan peluang mempunyai nilai lebih.
5) Mempunyai kemampuan manajerial untuk dapat merubah dan menggerakkan organisasi, (bukan bertahan pada status quo dengan sistem dan kondisi yang ada), sesuai dengan pilihan strategi perencanaan organisasi (Frinces, 2009).

6) Secara terus menerus melakukan perubahan dalam usaha menciptakan keunggulan mutlak walaupun kondisinya sudah di depan. Keenam jenis kualitas seorang pemimpin dalam era global memberikan kesan kepada kita bahwa yang dibutuhkan dari sosok seorang pemimpin adalah mereka yang sangat (Frinces, 2004) :

a) Dinamis - kerja keras

b) Visioner - berpandangan perspektif

c) Berpengaruh - membawa tim untuk kerja keras

d) Kompetensi (keahlian) - kemampuan menyelesaikan tugas.

e) Inovatif - entrepreneur, melakukan perubahan

f) Profesional - mampu mencapai tujuan strategis

\subsection{Dampak Positif dari Entrepreneurial Leadership}

Dampak positif dari prinsip-prinsip kepemimpinan kewirausahaan menurut Roebuck seperti yang dikutip oleh Zwilling (Zwilling, 2014)[17] yang dimuat oleh Majalah Forbes adalah :

\section{a. Fokus total terhadap pelayanan kepada pelanggan.}

Setiap anggota tim diaktifkan dekat ke garis depan pelanggan, sehingga mereka melihat bagaimana setiap fungsi berjalan atau tidak dalam memberikan nilai tambah layanan yang mereka berikan kepada pelanggan. Orang-orang pada organisasi yang lebih 
besar malah menjauh dari hari ke hari melakukan kontak dengan konsumen, dan akhirnya fokus perusahaan menjadi internal dan terisolasi.

\section{b. Mengoptimalkan risiko, tidak meminimalkannya.}

Resiko yang diperhitungkan harus diambil untuk memungkinkan perubahan, untuk memperbaiki, dan memenuhi kebutuhan pelanggan baru. Meminimalkan risiko pada akhirnya akan menyebabkan setiap perusahaan menjadi gagal. Kesalahan akan terjadi, sehingga tujuan tidak harus untuk menghilangkan semua kesalahan, tetapi untuk menangkap mereka sebelum mereka menciptakan bencana, dan menjadi berulang.

\section{c. Terus-menerus menjadi kreatif dan inovatif untuk mendapatkan yang lebih baik.}

Organisasi matang lupa bahwa perubahan adalah kesempatan, bukan ancaman. Namun tidak ada yang masih menyadari. Perubahan memungkinkan setiap orang untuk mendorong batas-batas dalam menanggapi, untuk meningkatkan peluang mereka untuk pertumbuhan diri, meningkatkan posisi kompetitif perusahaan dan peluang untuk sukses jangka panjang.

\section{d. Mengambil tanggung jawab pribadi untuk hasil organisasi.}

Sikap yang menjangkiti di dalam perusahaanperusahaan besar adalah bahwa individu karyawan tidak memiliki bertanggung jawab hasil di luar tujuan mereka sendiri. Hal ini menyebabkan seluruh perusahaan inefisiensi, komunikasi yang buruk, dan tidak selaras, dan juga cenderung mengurangi efektivitas setiap pemimpin individu.

\section{e. Memahami gambaran yang lebih luas.}

Untuk mendapatkan kinerja individu dan tim ke level tertinggi, setiap orang harus berkomitmen untuk visi, nilai-nilai, dan strategi organisasi, seperti halnya tujuan pribadi mereka. Sikap tidak bertanggung jawab di luar tujuan individu hampir selalu merugikan perusahaan.

\section{f. Menjaga hal-hal sederhana.}

Seiring waktu, orang-orang dalam organisasi besar cenderung membuat hal-hal yang lebih rumit dari yang mereka butuhkan untuk memulai. mungkin Ini untuk mengesankan orang lain dengan keahlian mereka, atau keinginan mereka untuk meminimalkan risiko. Pemimpin wirausaha tahu bahwa kompleksitas sebenarnya dapat meningkatkan risiko, serta kesalahan, dan akhirnya mengurangi kepuasan pelanggan.

\section{g. Memberikan inspirasi kepada Orang sekitar Anda dengan visi yang jelas dan sasaran.}

Orang-orang membutuhkan visi berbasis pelanggan dan beberapa bentuk tujuan akhir untuk memberikan makna mengapa mereka melakukan hal-hal tersebut, dan melibatkan mereka di luar pandangan internal mereka. Mereka juga perlu selangkah-demi-langkah membuat target untuk membantu mereka memvisualisasikan perjalanan ke tujuan itu, dan melihat bagaimana untuk mencapainya.

\section{Metodologi Penelitian}

Dalam penelitian ini, metode yang digunakan adalah studi literatur.

\subsection{Teknik Pengumpulan Data}

Dalam pengumpulan data, penulis mengumpulkan data referensi yang terkait dengan kepemimpinan wirausaha.

\subsection{Analisis Data}


Dalam penulisan kualitatif, penyajian data bisa dilakukan dengan bentuk uraian singkat, bagan, hubungan antar kategori dan sejenisnya, tetapi yang paling sering digunakan adalah teks yang bersifat naratif Sugiyono (2005).[18]

\section{Hasil Penelitian dan Pembahasan}

Para praktisi maupun akademisi melakukan berbagai penelitian tentang Entrepreneurship Leadership. Adapun hasil dari penelitian tersebut antara lain:

a. Chheda dan Banga (Chheda dan Banga, 2013) melakukan studi dampak kepemimpinan kewirausahaan terhadap kinerja Usaha Kecil dan Menengah di India. Hasil penelitian tersebut menunjukkan bahwa Continuous Improvement, Innovativeness, proaktif dan Alokasi Sumber Daya adalah empat komponen penting dalam kepemimpinan kewirausahaan yang memiliki dampak positif terhadap kinerja perusahaan. Hasil ini memiliki implikasi yang berharga bagi para pemimpin kewirausahaan, pengusaha masa depan dan akademisi.[19]

b. Wijaya dan Harjanti (Wijaya dan Harjanti, 2013) melakukan studi Enterpreneurial Leadership dan Hubungannya dengan Kinerja Bisnis pada Usaha Mikro Kecil di Wilayah Jawa Timur. Hasil penelitian menunjukkan bahwa adanya hubungan antara entrepreneurial leadership dengan kinerja bisnis pada usaha mikro dan kecil di wilayah Jawa Timur.[20]

c. Lisdiantini (Lisdiantini, 2013) melakukan studi Pengaruh Budaya Organisasi dan Kepemimpinan Kewirausahaan terhadap Motivasi Karyawan dan Dampaknya pada Peningkatan Kinerja Organisasi (Studi Pada PT Industri Kereta Api/INKA Madiun). Hasil dari penelitian tersebut menunjukkan diantaranya kepemimpinan kewirausahaan memiliki pengaruh positif dan signifikan langsung pada motivasi karyawan dan kepemimpinan kewirausahaan memiliki pengaruh positif dan signifikan langsung pada kinerja organisasi.[21]

\section{Kesimpulan}

Lingkungan bisnis yang cepat berubah dan persaingan global yang semakin ketat membutuhkan pemimpin yang kreatif, inovatif serta memiliki kemampuan komunikasi yang baik untuk menjawab tantangan tersebut. Selain itu diperlukan juga pemimpin yang visioner dan berani mengambil risiko dari tindakan yang diambil.

Berdasarkan tinjauan literatur, seperti yang diungkapkan oleh Fernald et al. (Fernald et al. 2005)[22] baik pemimpin dan pengusaha yang sukses adalah:

a. Kepemimpinan strategis (visi dan tujuan jangka panjang);

b. Kemampuan pemecahan masalah;

c. Tepat waktu dalam pengambilan keputusan;

d. Kesediaan untuk menerima risiko; dan

e. kemampuan negosiasi yang baik.

Pengembangan kepemimpinan wirausaha baik tingkat makro maupun mikro mutlak diperlukan dan terus diupayakan pelaksanaannya serta di evaluasi agar program pengembangan tersebut dapat berjalan dengan semestinya dan siap menghadapi tantangan global yang ada di depan mata.

\section{DAFTAR PUSTAKA}

\section{Paper dalam jurnal}

[1] McKinney Rogers Consultant. (2007). Entrepreneurship and the Corporate 
Environment. A study by McKinney Rogers into the role of entrepreneurship in the boardrooms of large global organizations.

[2] Purhantara, Wahyu. (2010). KEPEMIMPINAN BISNIS INDONESIA DI ERA PASAR BEBAS. Jurnal Ekonomi \& Pendidikan, Volume 7 Nomor 1, April 2010 .

[19] Chheda, Kavan., Banga, Charu. 2013. Impact of Entrepreneurial Leadership on Performance of Small and Medium Enterprises in India. Journal of Asia Entrepreneurship and Sustainability Vol XI Iss 2 December 2013, RossiSmith Academic Publications, Oxford, UK www.publicationsales.com.

[20] Wijaya, Yohan Hadi., Harjanti, Dhyah. 2013. Enterpreneurial Leadership dan Hubungannya dengan Kinerja Bisnis pada Usaha Mikro Kecil di Wilayah Jawa Timur. AGORA Vol. 1, No. 3, (2013).

[21] Lisdiantini, Netty. 2013. Pengaruh Budaya Organisasi dan Kepemimpinan Kewirausahaan terhadap Motivasi Karyawan dan Dampaknya pada Peningkatan Kinerja Organisasi (Studi Pada PT Industri Kereta Api/INKA Madiun). Widya Warta No. 02 Tahun XXXV II/ Juli 2013. ISSN 0854-1981.

\section{Buku}

[5] Rost, Joseph., C. (1993). Leadership for the twenty-first century. USA: Praeger Publishers.

[6] Robbins, Stephen P., Judge , Timothy A. (2013). Organizational behavior $15^{\text {th }} \mathrm{ed}$. New Jersey: Prentice Hall.

[7] Armstrong, Michael. (2009). Handbook of Human Resource Management Practice $11^{\text {th }}$ edition. London : Kogan Page.

[8] Wilkins, David., Carolin, Greg. (2013). Leadership Pure \& Simple, How
Transformative Leaders Create Winning Organizations. USA: McGraw-Hill.

[9] Bass, Bernard. M., Bass, Ruth. The Bass Handbook of Leadership: Theory, Research, and Managerial Applications. USA: The Free Press.

[10] Hesselbein, Frances., Goldsmith, Marshall. (2006). The leader of the future 2: visions, strategies, and practices for the new era. San Fransisco: Jossey Bass.

[11] Lussier, Robert N., Achua, Christopher F. (2010). LEADERSHIP Theory, Application, \& Skill Development $4^{\text {th }}$ edition. USA: South-Western Cengage Learning.

[12] Reynolds, Paul Davidson. (2007). Entrepreneurship in the United States: The Future Is Now. New York: Springer.

[13] Drucker, Peter F. (1985). Innovation and Entrepreneurship, Practice and Principles. New York: HarperCollins Publishers, Inc.

[14] Wijatno, Serian. 2011. Pengantar Entrepreneurship. Jakarta: Grasindo.

[15] Greenberg, Danna., Sweet, Kate McKone., Wilson, H. James. (2011). The New Entrepreneurial, Leader Developing Leaders Who Shape Social and Economic Opportunity. California: Berrett-Koehler Publishers, Inc.

[18] Sugiyono. (2005) Memahami Penelitian Kualitatif. Bandung: ALFABETA.

[22] Fernald, Lloyd W, Jr.,Solomon, George T., Tarabishy, Ayman. 2005. A New Paradigm: Entrepreneurial Leadership. Southern Business Review. Spring.

\section{Makalah seminar, lokakarya}

[4] Suyatno, Thomas. 2014. Cracking Zone Management. Bahan Kuliah ke-7 Kepemimpinan. S3 MSDM Universitas Negeri Jakarta. 


\section{Artikel dari internet}

[3] Suryamin. 2014. Nilai Ekspor Juli 2014

Melorot 8 Persen. www.tempo.co Diakses Tanggal 9 November 2014. Jam. 10.43 .

[16] Afiff, Faisal. 2012. Kepemimpinan Berbasis Kewirausahaan. http://fe.unpad.ac.id/id/arsip-fakultasekonomi-unpad/opini/2368 kepem impinan-berbasis-kewirausahaan. Diakses Tanggal 12 November 2014.

[17] Zwilling, Martin. 2014. Entrepreneurial Leadership Can Save Any Business. http://www.forbes.com/sites/martinzwilli ng/2014/09/17/entrepreneurial-leadership-cansave-any-business/. Diakses tanggal 13 November 2014. 